Article

\title{
From Digital Divide to Social Inclusion: A Tale of Mobile Platform Empowerment in Rural Areas
}

\author{
Lisha $\mathrm{Ye}^{*}$ and Huiqin Yang \\ Guanghua School of Management, Peking University, Beijing 100871, China; 1501110966@pku.edu.cn \\ * Correspondence: yelisha@pku.edu.cn
}

Received: 4 February 2020; Accepted: 9 March 2020; Published: 19 March 2020

\begin{abstract}
The digital divide in rural areas is an important social issue, especially in developing countries. Although Internet and broadband penetration have increased in the world generally, there are many obstacles for rural China to get access to ICT (Information and Communication Technology) and its services. The mobile platform is regarded as a novel and effective tool to reduce the digital divide. Based on a case of one mobile platform, namely WeCountry in Chinese rural areas, this study illustrates how a mobile platform bridges the digital divide and helps rural areas achieve social inclusion. Results show that: (1) the mobile platform mainly acts on the digital capability divide elimination, and it has to guide and increase users' usage capability; (2) the mobile platform can empower villagers in structural, psychological, and resource dimensions, achieving political inclusion, social participation inclusion, and economic inclusion; (3) platform providers and government are key organizations during the divide elimination process. This paper concludes with theoretical and practical implications.
\end{abstract}

Keywords: Digital divide; empowerment; social inclusion; mobile platform; rural areas

\section{Introduction}

The digital divide is a social and economic issue that has gained significant interest in recent years [13]. It refers to the disparity in access to and usage of information and communication technologies (ICTs) between individuals, households, businesses, and geographic areas [3,4]. In developing countries, digital divide in rural areas means that villagers lack access to Internet devices and opportunity to use information service [5]. There are some reasons why rural areas might confront digital divide compared with urban areas. The first reason is that the Internet and broadband infrastructures are relatively backward or hard to penetrate in rural areas. The second reason is that rural villagers may not afford a mobile device due to their low income. The third reason is that most of the villagers are ill-educated and it's hard for them to learn ICT skills [6]. Therefore, for rural residents, it is a serious obstacle to get external information, keep external contacts, and maintain access to public services [3]. It further results in rural hollowing, left-behind children, and empty-nest family issues, and urban-rural disparity in income, education, and healthcare [5]. Therefore, it is vital to bridge the digital divide in rural areas.

Studies show that the digital divide might cause political exclusion, social participation exclusion and economic exclusion [7-9]. In rural China, the digital divide is reflected villagers' limited access to information, emotion, and resources. Traditionally, rural residents keep informed through trumpet and bulletin from the village committee, and often miss important notifications. They participate in village affairs through the top-down approach, and always have no rights in decision making. They also have limited ways to communicate with others and can only build connections through face-to-face or telephones. Some young and middle-aged villagers who work in cities don't have sufficient channels to contact their left-behind children or parents. In addition, villagers earn money mainly by farming or 
rely on basic living allowances. It is difficult for them to make the best of what they own to get out of poverty. Therefore, villagers live in social exclusionary conditions [10-12]. Rural residents cannot fully participate in political, social, and economic life and build their own socially and culturally relevant connections and networks.

Social inclusion is regarded as a national desirable goal, which means that individuals can fully participate in political, social and economic life [13]. Studies show that ICT is a new way to reduce the digital divide, empower rural management in democratization and villager participation, promote marginalized groups joining in society, and alleviate the poverty issue $[1,14,15]$. Particularly, the mobile platform, making digital services available via mobile devices [16,17], is believed to give a great chance to narrow the digital divide as an innovative ICT. The mobile platform connects multi-actors, providing digital transaction and interaction service among actors [18,19]. However, studies show that only the access of technology is insufficient to promote social inclusion outcomes [1]. It also has to consider the usage and interaction between ICT and rural residents, the empowerment and benefits process, which then result in users' participation in society [11].

Enterprises, government, and other organizations play important roles in bridging digital divide and achieve social inclusion via ICTs, such as information infrastructure establishment, finance assistant, related supportive policy formulation, technology product design and training $[3,20]$. Their ICT-enabled development approaches benefit a lot from their profession, abundant resource, and practical capability. Existing studies mostly focus on the economic effect that ICTs bring about in rural areas [5,21]. The investment in ICTs infrastructure and productivity improvement resulted from information technology can contribute to income growth [22]. However, there are few studies focus on political participation and social interaction effect in rural areas [1].

Nowadays, the mobile platform, with its advantages of low cost, portability, and connectivity, is believed to give a great chance to narrow all political, social participation and economic divide and achieve related social inclusion [23,24]. Through connecting multi-actors and integrating different resources [18,19], the mobile platform can enhance transactional efficiency [25], facilitate interactions [26] and promote community building [27]. Studies have shown that mobile platform not only eliminates digital divide, but also play a vital role in communication and social participation. It can bring a sense of belonging and group identity by effective self-disclosure, contributing to higher well-being [28]. Therefore, how the mobile platform can empower rural residents to better social inclusion is worthy to be explored.

In this research, we consider the recent emergence of mobile platform in rural China, which is regarded as an innovative method to empower villagers and improve the rural development from digital divide to social inclusion. There are three questions addressed in this study:

(1) How does the mobile platform bridge digital divide in rural China?

(2) How does the mobile platform empower villagers and achieve social inclusion, especially in political management and social participation?

(3) How is the process from digital divide to social inclusion driven by organizations?

The rest of the paper is organized into six sections. Following the introduction, we provide a theoretical discussion of digital divide, mobile platform and social inclusion, and introduce the empowerment as the theoretical lens. Then we conduct a case study on WeCountry, a mobile platform used in rural areas, and illustrate the methodology. The subsequent section is a case description, followed by the discussion. Finally, we conclude the paper by highlighting theoretical and practical contributions.

\section{Theoretical Background}

\subsection{Digital Divide}

The digital divide is defined as "the gap between individuals, households, businesses and geographic areas at different socio-economic levels with regard both to their opportunities to access 
ICTs and to their use of the Internet for a wide variety of activities" [6,29]. It can be broken down into three levels. The digital access divide is the inequality of access to ICTs. It covers both hardware as well as software access [4]. Low penetration of ICT in rural areas mainly causes this first-level digital divide [11,14]. The digital capability divide is the difference in IT capability or computer skill levels [30]. Low-educated, poorly literate rural residents with little experience in using ICTs are easily marginalized $[5,6,31,32]$. The digital outcome divide is the inequality of outcomes of using IT, such as the differences in economic gains, learning performances, regional development and other benefits $[3,4,33]$. Most digital divide studies have focused on the digital access divide but there have been few studies on the digital capability divide and the digital outcome divide [4].

Digital divide can cause three types of social exclusions: (1) political exclusion, which means individuals or groups are excluded from exercising political and human rights [34]. Without ICTs, people cannot rapidly gain policy information, supervise government behavior, and vote in elections [35]. (2) Social participation exclusion relates to socially marginalized groups have limited ways to interact with others in everyday life and take part in social activities [36]. ICTs, such as social media, provide people with effective communication ways and promote information sharing [37]. Without its help, individuals cannot share information conveniently and participate in the community event, especially in online social context. (3) Economic exclusion: A disparity of ICTs contributes to the non-privileging of less wealthy groups because they have no access to technology and better education, which may contribute to unemployment and low income [7]. Bridging the digital divide is now given full attention to facilitate the progress of communities and regions in both developed [38] and developing countries [3].

In order to eliminate digital divide, many digital initiatives have emerged, and government, enterprises, NGOs (non-governmental organizations), cooperatives, and other organizations are the pioneers [7]. Governments formulate supportive policies and do investment in ICT infrastructure, which provides leadership and affects the development, adoption, and management of ICTs in public service [39]. NGOs and cooperatives put effort into some traditional activities such as self-building, community wind farms, collective insurance [40]. Enterprises mainly focus on financial donation and Internet-based application development against sickness and poverty in rural areas [3]. Because of their advantages in providing leadership, policies and implementation, financial resources and technical assistance [12], the access and adoption process of ICTs in rural areas can be guaranteed.

\subsection{Social Inclusion}

Social inclusion is "the extent that individuals, families, communities are able to fully participate in society and control their own destinies" [41]. Social inclusion has three aspects. (1) Political inclusion relates to a social group or individual citizen's ability to be involved in political activities, such as voicing their opinions, participating in democratic political decisions [35]. (2) Social participation inclusion relates to the extent to which a group or an individual participates in society, in terms of social interaction and interpersonal networks [35]. (3) Economic inclusion means people have plentiful job opportunities and can be productively engaged in train and work, leading to economic growth and poverty alleviation. The degree of participation in political democratization, social life and economic activities determine people's sense of belonging to society.

ICTs can enable various marginalized people to join an inclusive society [15]. For resettled refugees, ICTs are viewed as a useful resource that provides settlement services, helps them be socially connected and communicate effectively, and promotes their participation in a new resettled society $[1,5]$. For communities during natural disasters, social media empowers them to achieve collective participation, shared identification, and collaborative control [42]. In rural areas, it is also important that vulnerable rural residents, such as rural children, older people, rural women, etc., learn about the usage of ICTs, and that governments or firms take the lead in organizing inclusion-promoting projects [5].

It is worth mentioning that many scholars express that the pervasiveness or penetration of ICTs in an information society does not achieve social inclusion directly $[1,6]$. That is, merely providing the 
technology infrastructure or devices is not sufficient to promote social inclusion [5]. Accessing to ICTs is just the basis for social inclusion outcomes [35]. The focus is on the usage process and individual users should be empowered by ICTs. For instance, by offering ICTs applications that meet users' needs, improving the usability and simplicity of functions, enhancing users' technology skills [43], in order to solve users' problems by using ICTs in an adaptive manner [44].

\subsection{Empowerment}

Empowerment is a social development for the underprivileged, disadvantaged, or oppressed [45] in gaining greater control, efficacy, and social justice [46]. There are three dimensions of empowerment. (1) Structural empowerment is that power can be delegated to the powerless [47], namely improving the institutional structural conditions (e.g., authority delegation) and removing barriers that impede community access to information, opportunities and so on [42]. For example, changing policies or practices against the uneven distribution of power and expand the level and area of involvement [48]. Another example is affording a ICT platform as a channel for marginalized people to acquire information and voice their opinions [49]. (2) Psychological empowerment is a sense of meaning, self-determination, and impact [50] by providing psychological and emotional support, and cultivate a supportive climate, which can bring intrinsic motivation in production and life [1,42]. It focuses on the feeling of powerless people and they feel in control of their own destiny. (3) Resource empowerment relates to the ability to acquire, control, and manage resources, such as materials, capital, specialized knowledge and skills [42]. The resource can belong to both individuals and communities. For the latter one, it will motivate the collective behavior of all community members to manage and capitalize [51]. In this way, powerless individuals can have the ability to earn money and improve their life [52].

ICTs can empower rural people to achieve improvements in their lives [53]. For example, ICTs can hold much potential to empower rural women as helpers and enablers for family members [54]. The investment in rural broadband expansion can enhance local GDP growth [55]. The Alibaba's Taobao (e-commerce) Villages in remote China helps villages form an ecosystem and aid villagers' self-development and promote economic growth [12,31]. The ICT-supported platform in eKutir India progressively builds a self-sustaining ecosystem that can accelerate transformative change [22]. However, extant studies in rural development focus on the resource dimension of empowerment, and less on the structure and psychological dimensions. The structural and psychological empowerment in rural areas is crucial especially in terms of village management transparency, information communication efficiency and a sense of emotional self-determination, which are worthy to explore.

\subsection{Mobile Platform}

Mobile platform is a software tool that integrates resources, and provides services and content to support interactions and transactions among multiple sets of actors [56]. Mobile platform is based on smartphones or other portable devices and has the advantages of mobilization, connection, and interaction. It can deliver information accurately and promptly, facilitate interactions among multi-actors [26] and promote community building [27]. There are different types of mobile platforms, for example, transactional platforms serve as intermediaries between buyers and sellers [57], such as the mobile payment platform, including Apple Pay and Kakaopay [58]. Communication platforms support participants group communication, sharing and opinion expressions, such as social media, including Facebook and WeChat [19]. Participative platforms attract customers to participate actively in product improvement and to configure new service or business decision with the company together, for example, a company motivate and invite customers to participate in new product $R \& D$ [25].

In rural areas, mobile platforms play an important role mainly as the transactional and communication platforms. Although the majority of urban citizens can be connected to the Internet by mobile phones, most rural citizens in developing countries can hardly access to information services. Mobile platforms provide potential features or functionalities to overcome the barriers of distance through mobile connectivity [6], increasing farmers' access to public and private information, as well 
as linking buyers and sellers, facilitating agricultural data collection and improving access to financial services [59]. However, the mobile platform enabled ICT innovation in rural areas is relatively new and yet has not been studied much in the academic field. With government and other organization realize the value of the mobile platform and promote its application in rural areas, it is necessary to research how this latest ICT application driven by organizations empowers villagers, especially in structural and psychological aspects, and what effects it brings about.

Figure 1 shows the relationship of core concepts of our research.

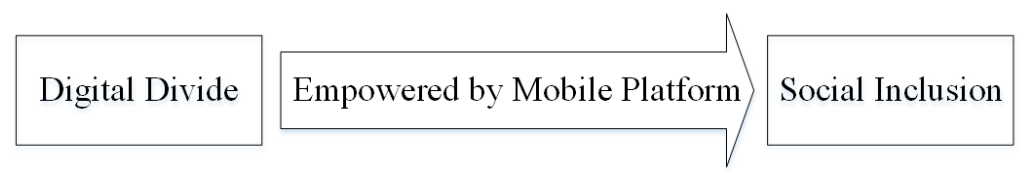

Figure 1. The Relationship among digital divide, social inclusion, empowerment and mobile platform.

\section{Methodology}

We adopt a case study methodology to study how mobile platform empowers rural development from digital divide to social inclusion for the following reasons. First, we aim to uncover "how" questions [60]. Adequate explanations and broader causal linkages that are deeply embedded in complex contexts make case study a proper choice towards theory building. Second, the phenomenon of our study is an emerging, intricate, and yet rare occurrence of an event that has begun to attract academic attention [61]. Case study is very appropriate for such exploratory research.

\subsection{Sample Selection}

In this study, we focused on a mobile platform called WeCountry and its usage in Heze City, Shandong Province, China. The location of Heze city in China can be seen in Figure 2. WeCountry is a mobile portal built on the social software WeChat operated by Tencent since 2015. Each village has its own entrance to the village service. With WeCountry, the village committee can publish policy information and village affairs notice, and rural residents can directly receive it on the platform and make comments. Besides, villagers can share their feelings with fellow villagers, and even sell agriculture products to urban dwellers. WeCountry has brought about an enormous effect on rural development. Up to now, there are more than 15,000 villages and 2 million villagers using the platform, covering Shandong, Hunan, Guizhou, Sichuan, and nearly 20 provinces. In Heze City, WeCountry works best in terms of the widest and active users' participation in local rural areas compared with other cities. The number of online villages accounts for nearly $90 \%$ and the villagers' participation level ranks top among all villages. Therefore, the usage of WeCountry in Heze City was a representative case to interpret the research questions. 


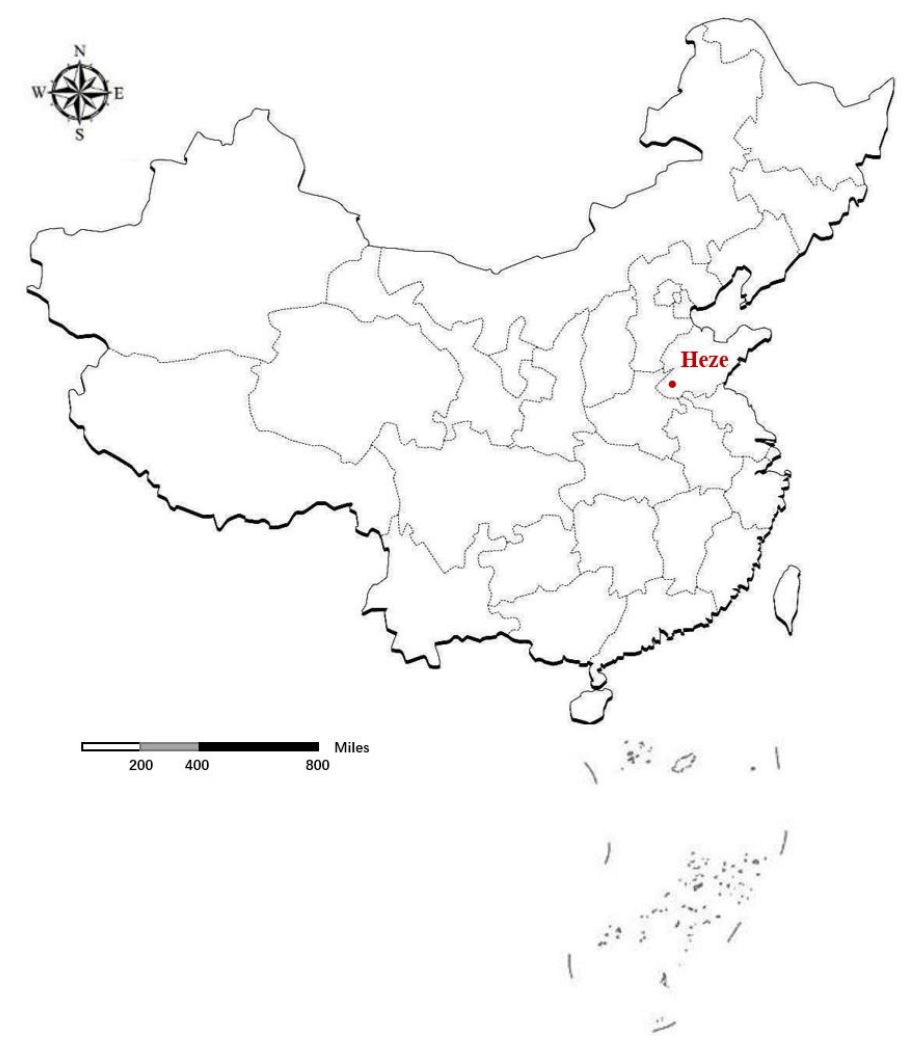

Figure 2. The Location of Heze City in China.

\subsection{Data Collection}

We collected abundant materials from various data sources, including face-to-face interviews and archival materials, which serve to form data triangulation. First-hand materials came from in-depth interviews and informal interviews. We visited eight villages in Heze City in September 2017 and conducted 40 interviews, with 4 WeCountry staff, 13 government officials, 10 WeCountry administrators, 8 members of village committee, and 29 villagers. All interviews were recorded and transcribed to ensure data accuracy. We also collected second-hand materials include information in WeCountry platform, internal materials of villages, social media materials, and academic materials.

\subsection{Data Analysis}

We began analyzing data as we collected it [62]. Depending on background information, broad interviews, and related literature, we conceptualized the phenomenon and did the first-order coding. We identified relevant concepts like digital divide, mobile platform, empowerment, social inclusion as core model elements to guide our further data collection and case analysis. Then, we did the second-order coding, including collecting initial interview data and organizing them to construct and extend our theoretical lens. According to the theory of empowerment, we summarized the narratives about WeCountry in table, and identify how it empowers villages, formatting the third-order coding [63]. We attempted to search for and explicate the pattern of social inclusion that the mobile platform realizes. Further, we identified which kind of organizations help this empowerment process and what role do they play. The iteration of data collection and theoretical construction continues until we believe that the theoretical lens was an accurate representation of eventual case data [60]. Then we consistently ensured alignment between data, theory, and findings, including steps like confirming and validating data, selective coding, and ensuring theory data alignment [64]. We used multiple data sources (interviews, news report, and archival data) to ensure that the data was consistent [65]. Following the data coding guidelines, two researchers cooperated in data coding and arranging them 
into the identified set of themes. Our theoretical lens was improved during the recursively iterating between existing theories, data, and the emergent model until theory-data-model alignment and theoretical saturation have been reached [60].

\section{Case Description}

For a long time, Heze has long been an underdeveloped region. Located in a remote area with inconvenient transportation, its economic development has been slower than the average level of Shandong Province. In addition, there are a large of the rural population in Heze. Although there are basic ICT infrastructures in Heze, most of the rural residents still have difficulties in accessing ICT devices or services. For one thing, it's difficult for them to afford a mobile phone due to their low income. For another, most of them are ill-educated and there are many old people living in villages. These people are lack of ICT skills and do not have much motivation to learn something new.

In Heze city, the digital divide is reflected in villagers' limited access to the Internet and their lack of IT knowledge and skills. It can cause three main problems. The first problem is inefficient information communication. Traditional policy delivery methods are top-down, by oral communication and broadcast. Villagers cannot receive notification and related solutions promptly and may miss some important notice from the village committee, a self-organization which is in charge of village management. It is also difficult for them to voice their opinion on their village development and take part in the village affairs' decision making. Therefore, villagers show low participation in village management and suffer alienation from the village manager.

The second problem is mental deprivation. For most villagers, they engage in physically productive activities such as farming, breeding, and handcrafting. They are exhausted with the heavy labor work but have limited ways, such as face-to-face or telephone conversation, to communicate, share feelings, and relieve pressure. Besides, many empty-nest families exit and there is lack of effective and prompt approaches for migrant parents to contact their children and express their missing. Therefore, villagers cannot fully interact with family members and fellow villagers and gain enough emotional support.

The third problem is high poverty. Local villagers are engaged in agriculture, and have little opportunities in employment, leading to low income and living conditions. Young and middle-aged villagers began to out-migrate to the city for better jobs, which results in rural hollowing and exacerbates rural distress. Therefore, rural residents cannot fully participate in political, social, and economic life and build their own socially and culturally relevant connections and networks.

\subsection{From Digital Divide to Mobile Platform Access}

In order to solve the rural problems caused by the digital divide, the government in Heze City tries to seek help from ICTs practices. In December 2016, a report about an innovative mobile platform implementation, namely WeCountry, in rural areas was published in People's Daily, the most authoritative and popular newspaper in China. This report recorded how WeCountry had brought an enormous change in some impoverished villages in China, especially in terms of information, emotion, and resource exchanges. Inspired by this report, the government in Heze City became aware that WeCountry could also work in their village. According to the government official interviewee 1 :

We are always thinking about how to use ICTs to improve our rural areas. Although several years ago we tried rural e-commerce, we came across bottleneck thinking as to what are the next directions of our rural development. The report in People's Daily enlightened us that we can switch to a new point in village management and emotional communication as well as economy.

The government organized an investigation into certain villages that had successfully implemented WeCountry, such as Tongguan village in Guizhou Province. After they assured that WeCountry was deserved to put into practice in their own rural villages, they made supportive policies, built an 
implementation system, and called on grassroots leaders to participate in WeCountry adoption and usage. Interviewee 2, one of the governmental officials, recalled their practices:

In 2017, our municipal government set WeCountry as a new strategical approach to poverty alleviation. In the annual governmental work report, we put forward that we would have to generalize WeCountry to at least 100 villages. In order to achieve the goal, the government at all levels, from city to local villages, had to report and assess the rate of the generalization process. Well-behaved regions would be praised while ill-behaved regions would be criticized.

We also called on grassroots leaders to advertise WeCountry. Villagers got access to WeCountry by specific $Q R$ code. Thus, our members of the village committee were mobilized to print the QR code and deliver it to fellow villagers from door to door or in public place. It was very useful because these grassroots leaders have high prestige. Most villagers trusted them and would scan a QR code and get access to WeCountry.

Tencent, as the platform provider, also played an important role in helping villagers access to WeCountry. Some of ICT experts who had WeCountry operation experience came to visit Heze City and guided related implementation work. Considering villagers were in poor economic conditions and may have difficulties in possessing smartphones, Tencent was also sought for certain enterprise resources, as well as China Mobile and ZTE Corp, as mobile telecom operators and mobile device providers. Mobile device providers offered villagers mobile phones at discount or even for free, and the mobile telecom operator built mobile communication base stations, guaranteeing the mobile service provision. According to interviewee 3, the leader of WeCountry expert team:

Our team consisted of public-spirited people. We devoted to China's poverty reduction from 2009 and put much effort in rural development. In 2015, we found that the mobile platform may be an innovative and effective way to bridge digital divide, leveraging the advantages of Internet. Thus, we contact positively with the local government, villages, and enterprises, and want to help rural areas by collective power, no matter the capital, experience, or policy aspects.

\subsection{The Use of Mobile Platforms and Empowerment}

WeCountry provides villagers with more than 20 functions, which can be divided into three functional types: village information management, affective interaction, and e-commerce. In village information management functions, the village committee can publish information, including government information (e.g., policy, notice) from superior government, village affairs information such as rural daily collective activities, financial information such as compensation, project funds, salary payment, and fees related to villagers' production and life. Rural residents can receive the information timely, make comments, and also raise their doubts and questions in the corresponding information or directly ask the village secretary. When the village committee receives different opinions about decisions, they will give feedback very soon.

Take A Village as an example, it was in a coal mining collapse area and local villagers can receive compensation for living losses. The village committee takes responsibility for informing each village about it. However, before using WeCountry, compensation information was not publicly and transparent, resulting in villagers' dissatisfaction to the village committee. Since WeCountry came into use, the situation has been improved. As interviewee 4, the WeCountry administrator in A Village said:

On March 12, 2017, the next day that we used WeCountry, I posted detail information about compensation, including government policy on the compensation standard. There were 731 villagers that click this message, 98 people made comments, 85 people participated in giving a mark. Many villagers told us that they were very satisfied with this practice and thought that they can receive what they deserved. 
Interviewee 5, a village secretary in A Village, also described the changes that happened after he used WeCountry:

Many villagers inquired me on WeCountry nowadays. Although I am busy at work, I check WeCountry every night before sleep. Our villagers cared about issues healthcare, minimal assurance, requisition of land, party building and collective activity that are very close to their life. Thus, I have made the promise that I have to reply to villagers within 24 hours and solve the problems.

Affective interaction functions allow villagers to share their life and emotion on the platform and fellow villagers can favorite it and make comments to it. Interviewee 6, the women's director of E Village, is one of the typical villagers that psychologically empowered by WeCountry. Before WeCountry, her life was very simple and tedium. The main thing that she did in daily life was to take care of aged people in a nursing home. Since she begun to use WeCountry, she has a method to broaden her horizons and know the outside world. She has more self-determined actions to make her life become abundant and interesting. As she said:

Nowadays, I always walk around in our countryside and find some meaningful things proactively, such as beautiful scenery in picking garden or farm work in farmland. I will take photos, edit some words, and post them on WeCountry. Lots of fellow villages "like" my messages and interact with me actively.

For some migrant villagers, the affective interaction functions connect them with their families living in the hometown. Through WeCountry, they can keep up with the latest news on their village, alleviating homesickness and the sense of separation. Migrant parents can know their children's education environment and follow study performance better. Besides, parents can post questions on the platform and contact with school headmasters or teachers directly. For "left-behind" children, it is vitally necessary for their parents to obtain educational information and communicate with schools. As interviewee 7 , the village secretary of D Village mentioned:

Our village is a hollow village. Most young and middle-aged people migrate to urban cities to make money. I appeal to them to join WeCountry. Not only can they see everything happening in the village, but also interact with villagers. Especially for migrant parents, they can hardly fully participate in their children's education and growth. I told them to use the school and the home's connection function. They can see each notification published by the school.

E-commerce functions promote agricultural products transaction. Villagers are encouraged to sell agricultural products or handicrafts in WeCountry and create income. The whole village can participate in this process, including find available supplies, design logos, package products, upload to the e-commerce platform, and manage online sales, logistics, and after-sale services. Interviewee 8 , the village secretary of $C$ Village, illustrates the practice of selling products with pride:

Our village does best in selling agricultural products among all the villages in our district. We sell green beans, pears, apples, grapes, peaches, garlic, turtles. So far, online sales have been more than tens of thousands of yuan. Many urban residents told us that the pears really tasted good. Our Town helps us establish a cooperative and unified brand to centralism management and sales. Besides, we look for professional designers to design our products' logo and pack. There are also some villagers responsible for writing an advertisement and posting on the platform.

C Village also makes full use of its planting industry as a countryside scenery. So far, it has already held the pear flower festival and other cultural tourism festivals, which appealed to lots of city dwellers 
and caused a great sensation. In the next year, C Village plans to hold the rose festival, with the aims of building their brand of countryside tourism, attracting residents from other villages or cities, and increasing local income.

\subsection{The Achievement of Social Inclusion}

For WeCountry's better usage, each village selected at least one WeCounrty administrator from common villagers, who in charge of identity verification, content regulation, and trouble solution. Under Tencent experts' guidance, local government organized usage training for WeCounrty administrators regularly. WeCountry administrators were mainly responsible for training aged or undereducated villagers who have difficulties in using mobile phones and cultivated their ICT capabilities. Statistically, by the end of 2017, there had been 220 training courses and more than 36 thousand villagers were trained in Heze City.

Moreover, in order to stimulate villagers' participation, Tencent established an activeness rank system for villages on the home page, called WeCountry Index. It depended on a village's mobile platform activeness, namely, how many villagers and how often did they interact on WeCountry. The rank of villages was visible to all online villagers, and it would stimulate villager usage for higher rank because of their sense of collectivity in their own village. Top villages in WeCountry Index would be rewarded a bonus, and typical representative villages publicized nationwide. Interviewee 6 in $\mathrm{E}$ Village talked about her extremely focus on WeCountry Index:

I am very active in WeCountry. Every night, I stay up to twelve o'clock and update the WeCountry to check whether my village was rated as the most active village in the past day. I feel very excited if my village ranks first among all villages because I contribute to it. I think it is a very honorable and fulfilling thing.

The government takes WeCountry Index as assessments of their subordinate governments in ICTs generalization work. Every day, cadres of subordinate governments have to report to the superior government about the current WeCountry implementation situation, assess and provide improved implementation plans. Up to the end of 2017, there had been 5151 villages using WeCountry and about 1.78 million villagers certificated in this platform, which was the most among all Chinese cities. On the WeCountry Index, Heze City ranked first most of the time in 2017. Due to the successful practice and favorable effect, Heze City was regarded as a good example in ICT usage for other cities learning from.

Villagers in Heze City expressed their achievements benefited from WeCountry. Interviewee 9 in $\mathrm{H}$ Village said WeCountry improved their village management to a large extend:

(With WeCountry) It is more convenient for us to participate in village management. Originally, the village committee only posted notifications on the bulletin board or we have to ask them face to face. With WeCountry, we can receive announcements directly on the platform. It is so convenient that without leaving home, we villagers can know what happened in the countryside.

One villager interviewee 10 in E village, who was also as WeCountry administrator in her village, acknowledged the economic benefit that villagers can get from WeCountry, but she regarded that a more abundant spiritual life that WeCountry brought changed villagers most:

As a WeCountry administrator, I contact with my fellow villagers almost every day. They mostly use WeCountry for information acquisition, sharing and make money. Poverty is a major problem that we faced nowadays, and WeCountry provides a channel for we villagers to turn an extant rural resource into money. Many villagers can show their particular workmanship or plants online and achieve earnings.

However, during the process I teach them using WeCountry, I find that the biggest change is that they can broaden their horizon, know what happened outside of the village, and 
even participate in online social interaction activities. Especially for aged or undereducated people, WeCountry is really a good platform for them to see the outside world and make connections with people through the Internet.

\section{Discussions}

\subsection{Mobile Platform Bridges Digital Divide through Three Types of Functions}

According to our analysis, the mobile platform bridges digital divide in rural areas through three types of functions, namely village information management, affective interaction, and e-commerce, which can be classified into corresponding platforms. The village information management platform changes the information delivery structure and provides a channel for common villagers to acquire information and communicate with grassroots leaders. For the Chinese government and village committee, it is important for remoted village community management. It improves villagers' participation in rural management by guaranteeing information transparency and interactions between villagers and government. The affective interaction platform allows rural residents to share their thoughts, ideas, feelings with word and photos. It connects all villages tightly, no matter they live in the countryside or not, giving rise to a sense of togetherness and collective energy. Especially for migrant parents, they can also take part in their childrens' education. The agricultural e-commerce platform provides a channel to link rural areas to urban areas and empowers villagers by facilitating the capitalization and development of the local resource. During traditional products or handicrafts transaction on the platform, local villagers learn how to choose or create valuable products, leverage new ICT to make these resources capitalized, and promote the flow of funds from cities to villages, contributing to job opportunities and income growth in rural areas.

The reason why these three types of platforms bridge digital divide in rural areas is they meet the villagers' needs preciously and in line with the current rural situations in terms of inefficient information communication, mental deprivation and high poverty. According to the theory of digital divide, the digital capability divide, related to ICT capability or users' ability to use ICT [4], is a more important part that ICT acts on. But existing studies tend to study digital capability divide from the perspective of users. They point out that users' skills and experience in using ICTs determine their usage ability. Under this circumstance, users' education and work conditions are significant [4]. However, we find that ICTs should also play a key role in increasing users' usage ability. Well-designed functions and friendly interaction interfaces can promote users' usability and satisfaction. In our case, WeCountry provides three kinds of platforms matching well with villagers' need. Moreover, the platform has gone through at least three big iterations and numerous small changes. The goal is to provide practical and facilitate functions for rural residents.

\subsection{Three Types of Empowerments Achieving Social Inclusion Outcomes}

From digital divide to social inclusion, three types of mobile platforms mainly empower villagers through structural, psychological and resource empowerment. The interaction between villagers and these functions facilitate village information, emotion, local assets, and capital resources transferred transparently and quickly among members of village commitment, ICT administrators, migrant and non-migrant villagers, and urban residents. In structural empowerment, the information barriers are broken, and the information flow among governments, grassroots leaders and villagers transferred transparently and quickly. Villagers have the power to be engaged in village politic management and express their opinions. can enhance the villagers' trust in the village committee and contribute to protecting the villagers' rights and interests, so as to arouse villagers' enthusiasm in rural management and promote political inclusion. In psychological empowerment, emotional sharing and daily communication are not limited to location, thus villagers can participate in virtual activities and enlarge their social life, especially helping alleviate the sense of isolation and alienation for migrant villagers. In resource empowerment, villagers have access to agricultural assets, sell them and gain money 
with the help of mobile platforms, solving problems of poverty. That is, through three empowerment dimensions, mobile platforms help villagers participate in village management, social activities and income growth, achieving political inclusion, social participation inclusion, and economic inclusion.

In these three empowerments, existing studies regard economic development as the main way to solve rural problems, which emphasize on the resource empowerment [12,31]. Although economic income is essential to rural residents, which is equated to material life, villagers' political and spiritual lives are also important [66]. Corresponding to the rural current situations, inefficient management, and mental deprivation, we identify another two kinds of empowerment, structural and psychological empowerment. These two empowerments are especially significant for rural China and have to be paid close attention to. The essence of empowerment is to combine technology design with users' need, and to stimulate villagers to have the willpower to achieve a better life through ICT usage.

\subsection{The Roles of Organizations Enabling Villages from Digital Divide to Social Inclusion}

Mobile platform cannot effectively empower villagers itself, which requires the joint efforts of mobile device providers and mobile telecom operators, platform providers and government, especially the latter two, which play significant roles in eliminating digital capability divide.

The platform provider serves as the usage trainer and motivator. Specifically, platform providers provide ICT training for users, set usage rule and assessment system to guide and stimulate users' participation. Tencent held training classes in WeCountry usage and management skill.

The government plays as policy-maker and organizer. As we all know, the main aim of policy-makers has been to minimize regional disparities. For Heze City, rural hollowing and left-behind children issues are serious, and the economy level ranks at the bottom of Shandong Province. In early 2017, enlightened by the mobile platform, the local government decided to use WeCountry to improve rural management and increase GDP. Besides, the application of the mobile platform was listed into the government work report to emphasize its significance and selected the Yuncheng County as a trial. The government, with its politic authority and strong executive system, formulates supportive policy and promotes the popularization of mobile platforms in rural areas.

In Figure 3, we summarize our findings of how mobile platform empowers villages and eliminate digital divide.

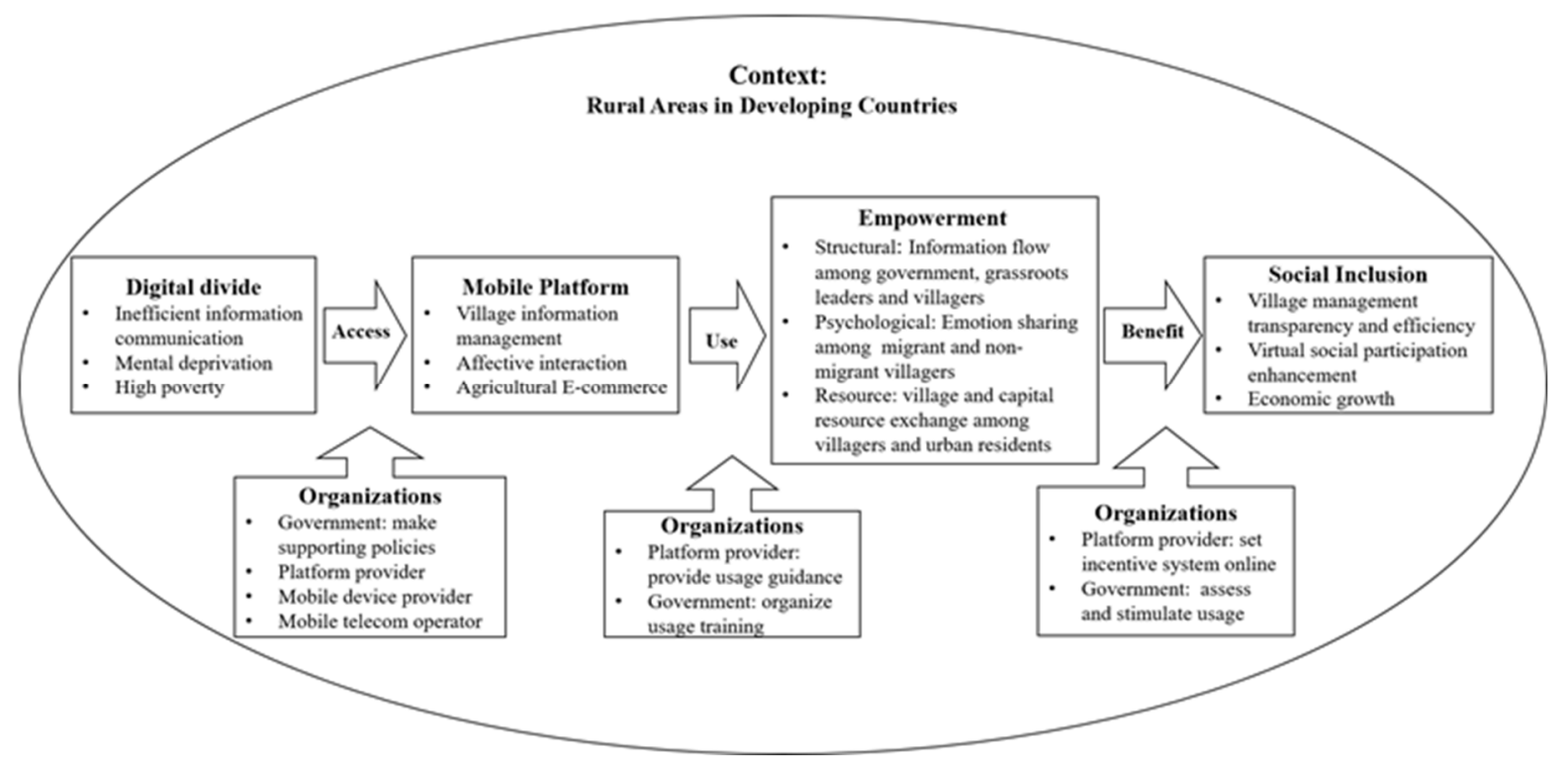

Figure 3. How Mobile Platform Empowers Villagers to Eliminate Digital Divide. 


\section{Conclusions}

This paper presents a revelatory case whereby a mobile platform eliminates digital divide and empowers villagers to social inclusion. With the advantages of information transparency, emotion interaction, and resource transaction, the mobile platform connects local government, village committee, farmers, migrant villagers and urban citizens. It provides three types of functions: village management, affective interaction, and e-commerce, corresponding to structural empowerment, psychological empowerment, and resource empowerment. There are three dimensions of social inclusion that can be achieved, namely political inclusion, social participation inclusion, and economic inclusion.

During the digital divide elimination process, two organizations, platform providers and government play a part in it. Platform provider provide practical and friendly functions and help users improve their skills through training. Further, it sets an incentive system and regulation to guide villagers' high participation. Government serves as the policymaker and organizer, and enhance the divide elimination by formulating policies and ensuring the ICT implementation.

\subsection{Theoretical Implications}

First, as a new ICT application in rural areas, mobile platforms can narrow the digital divide and provide for villagers with various functions in terms of village management, emotion interaction, and e-commerce, which solve traditional rural problems, such as inefficient village management, mental deprivation, and high poverty. Second, mobile platforms mainly act on the capability divide elimination. The key is to combine technology design with rural needs and stimulate villagers' willpower. Third, empowerment is multidimensional. Although many scholars focus on the resource dimension, it is necessary to study the structural and psychological dimensions, for these two are also important parts in rural development.

\subsection{Practical Implications}

First, a good ICT application must attract users and keep users as long as possible. This requires ICT providers to investigate repeatedly, fully understand users' need and design practical functions. Further, setting suitable participation rules and incentives can guide users as well as increase their enthusiasm and loyalty. Second, for China, the top-down approach for government is an effective way in ICT application popularization, implementation, and development. From the experience of Heze municipal government, the WeCountry used in the local village works better than other regions, which can be learned by other governments. We hope to see that government interference can stimulate the endogenous power of rural villagers and let them use ICTs spontaneously and sustainably in the future. However, whether rural villagers can use ICTs spontaneously without government interference, it could be a long-term study and deserves to be discussed in future.

Author Contributions: Conceptualization, L.Y. and H.Y.; methodology, L.Y.; validation, H.Y.; formal analysis, L.Y. and H.Y.; investigation, L.Y.; writing — original draft preparation, L.Y.; writing-review and editing, L.Y. and H.Y. All authors have read and agreed to the published version of the manuscript.

Funding: This research received no external funding.

Conflicts of Interest: The authors declare no conflict of interest.

\section{References}

1. Andrade, A.D.; Doolin, B. Information and communication technology and the social inclusion of refugees. MIS Q. 2016, 40, 405-416. [CrossRef]

2. Greenwood, B.N.; Agarwal, R. Matching Platforms and HIV Incidence: An Empirical Investigation of Race, Gender, and Socio-Economic Status. Soc. Sci. Electron. Publ. 2016, 62, 2281-2303.

3. Venkatesh, V.; Sykes, T.A. Digital Divide Initiative Success in Developing Countries: A Longitudinal Field Study in a Village in India. Inf. Syst. Res. 2013, 24, 239-260. [CrossRef] 
4. Wei, K.K.; Teo, H.H.; Chan, H.C.; Tan, B.C.Y. Conceptualizing and Testing a Social Cognitive Model of the Digital Divide. Inf. Syst. Res. 2011, 22, 170-187. [CrossRef]

5. Salemink, K.; Strijker, D.; Bosworth, G. Rural development in the digital age: A systematic literature review on unequal ICT availability, adoption, and use in rural areas. J. Rural Stud. 2017, 54, 360-371. [CrossRef]

6. Park, S. Digital inequalities in rural Australia: A double jeopardy of remoteness and social exclusion. J. Rural Stud. 2017, 54, 399-407. [CrossRef]

7. Barry, J.J. Crossing the Digital Divide: Is Access to the Internet an Economic Right? SSRN Electron. J. 2013. [CrossRef]

8. OECD. Bridging the Rural Digital Divide; OECD Publishing: Paris, France, 2018.

9. Wamuyu, P.K. Bridging the digital divide among low income urban communities. Leveraging use of Community Technology Centers. Telemat. Inform. 2017, 34, 1709-1720. [CrossRef]

10. Lai, P.H.; Lyons, K.D.; Kyle, G.T.; Kreuter, U.P. Coping with change in rural landscapes: The psychological stress of rural residents experiencing unconventional gas developments. Land Use Policy Int. J. Cover. All Asp. Land Use 2017, 67, 487-497. [CrossRef]

11. Yu, T.K.; Lin, M.L.; Liao, Y.K. Understanding factors influencing information communication technology adoption behavior: The moderators of information literacy and digital skills. Comput. Hum. Behav. 2017, 71, 196-208. [CrossRef]

12. Leong, C.; Pan, S.L.; Newell, S.; Cui, L. The emergence of self-organizing e-commerce ecosystems in remote villages of china: A tale of digital empowerment for rural development. MIS Q. 2016, 40, 475-484. [CrossRef]

13. Shortall, S. Are rural development programmes socially inclusive? Social inclusion, civic engagement, participation, and social capital: Exploring the differences. J. Rural Stud. 2008, 24, 450-457. [CrossRef]

14. Gerpott, T.J.; Ahmadi, N. Composite indices for the evaluation of a country's information technology development level: Extensions of the IDI of the ITU. Technol. Forecast. Soc. Chang. 2015, 98, 174-185. [CrossRef]

15. Haight, M.; Quanhaase, A.; Corbett, B.A. Revisiting the digital divide in Canada: The impact of demographic factors on access to the internet, level of online activity, and social networking site usage. Inf. Commun. Soc. 2014, 17, 503-519. [CrossRef]

16. Hong, S.J.; Tam, K.Y. Understanding the Adoption of Multipurpose Information Appliances: The Case of Mobile Data Services. Inf. Syst. Res. 2006, 17, 162-179. [CrossRef]

17. Lee, S.H.; Shin, B.; Lee, H.G. Understanding Post-adoption Usage of Mobile Data Services: The Role of Supplier-side Variables. J. Assoc. Inf. Syst. 2009, 10, 860-888. [CrossRef]

18. Barrett, M.; Oborn, E.; Orlikowski, W. Creating Value in Online Communities: The Sociomaterial Configuring of Strategy, Platform, and Stakeholder Engagement. Inf. Syst. Res. 2016, 27, 704-723. [CrossRef]

19. Singaraju, S.P.; Quan, A.N.; Niininen, O.; Sullivan-Mort, G. Social media and value co-creation in multi-stakeholder systems: A resource integration approach. Ind. Market. Manag. 2016, 54, 44-55. [CrossRef]

20. Chen, R.S.; Liu, I.F. Research on the effectiveness of information technology in reducing the Rural-Urban Knowledge Divide. Comput. Educ. 2013, 63, 437-445. [CrossRef]

21. Okunola, O.M.; Rowley, J.; Johnson, F. The multi-dimensional digital divide: Perspectives from an e-government portal in Nigeria. Gov. Inf. Q. 2017, 34, 329-339. [CrossRef]

22. Jha, S.K.; Pinsonneault, A.; Dubé, L. The evolution of an ICT platform-enabled ecosystem for poverty alleviation: The case of eKutir. MIS Q. 2016, 40, 431-445. [CrossRef]

23. Sørensen, C.; Reuver, M.D.; Basole, R.C. Mobile platforms and ecosystems. J. Inf. Technol. 2015, 30, $195-197$. [CrossRef]

24. Karippacheril, T.G.; Nikayin, F.; De Reuver, M.; Bouwman, H. Serving the poor: Multisided mobile service platforms, openness, competition, collaboration and the struggle for leadership. Telecommun. Policy 2013, 37, 24-34. [CrossRef]

25. Xie, K.; Wu, Y.; Xiao, J.; Hu, Q. Value co-creation between firms and customers: The role of big data-based cooperative assets. Inf. Manag. 2016, 53, 1034-1048. [CrossRef]

26. Kallinikos, J.; Tempini, N. Patient Data as Medical Facts: Social Media Practices as a Foundation for Medical Knowledge Creation. Inf. Syst. Res. 2014, 25, 817-833. [CrossRef]

27. Culnan, M.J.; Mchugh, P.J.; Zubillaga, J.I. How Large U.S. Companies Can Use Twitter and Other Social Media to Gain Business Value. MIS Q. Exec. 2010, 9, 243-259. 
28. Smith, R.; Morgan, J.; Monks, C. Students' perceptions of the effect of social media ostracism on wellbeing. Comput. Hum. Behav. 2017, 68, 276-285. [CrossRef]

29. Iivari, N.; Kinnula, M.; Molin-Juustila, T.; Kuure, L. Exclusions in social inclusion projects: Struggles in involving children in digital technology development. Inf. Syst. J. 2018, 28, 1020-1048. [CrossRef]

30. Dewan, S.; Ganley, D.; Kraemer, K.L. Across the Digital Divide: A Cross-Country Analysis of the Determinants. J. Assoc. Inf. Syst. 2005, 6, 6-12.

31. Cui, M.; Pan, S.L.; Newell, S.; Cui, L. Strategy, Resource Orchestration and E-commerce Enabled Social Innovation in Rural China. J. Strateg. Inf. Syst. 2017, 26, 3-21. [CrossRef]

32. Song, Z.; Song, T.; Yang, Y.; Wang, Z. Spatial-Temporal Characteristics and Determinants of Digital Divide in China: A Multivariate Spatial Analysis. Sustainability 2019, 11, 4529. [CrossRef]

33. Lin, J.; Yu, Z.; Wei, Y.D.; Wang, M. Internet access, spillover and regional development in China. Sustainability 2017, 9, 946. [CrossRef]

34. Chigona, W.; Beukes, D.; Vally, J.; Tanner, M. Can Mobile Internet Help Alleviate Social Exclusion in Developing Countries? EJISDC Electron. J. Inf. Syst. Dev. Ctries. 2009, 36, 1-16. [CrossRef]

35. Selwyn, N. 'E-stablishing' an Inclusive Society? Technology, Social Exclusion and UK Government Policy Making. J. Soc. Policy 2002, 31, 1-20. [CrossRef]

36. Newman, L.; Browne-Yung, K.; Raghavendra, P.; Wood, D.; Grace, E. Applying a critical approach to investigate barriers to digital inclusion and online social networking among young people with disabilities. Inf. Syst. J. 2017, 27, 559-588. [CrossRef]

37. Onitsuka, K. How Social Media Can Foster Social Innovation in Disadvantaged Rural Communities. Sustainability 2019, 11, 2697. [CrossRef]

38. Hsieh, P.A.; Rai, A.; Keil, M. Addressing Digital Inequality for the Socioeconomically Disadvantaged Through Government Initiatives: Forms of Capital That Affect ICT Utilization. Inf. Syst. Res. 2011, 22, 233-253. [CrossRef]

39. Pang, M. Politics and Information Technology Investments in the U.S. Federal Government in 2003-2015. Inf. Syst. Res. 2017, 28, 1-42. [CrossRef]

40. Miller, D.T. Rediscovering Social Innovation. Stanf. Soc. Innov. Re. 2008, 6, 34-43.

41. Warschauer, M. Technology and Social Inclusion: Rethinking the Digital Divide. Libr. Rev. 2004, 71, $709-733$.

42. Ling, C.L.M.; Pan, S.L.; Ractham, P.; Kaewkitipong, L. ICT-enabled community empowerment in crisis response: Social media in Thailand flooding 2011. J. Assoc. Inf. Syst. 2015, 16, 174-212. [CrossRef]

43. Briggeman, B.C.; Whitacre, B.E. Farming and the Internet: Reasons for Non-Use. Agric. Resour. Econ. Rev. 2010, 39, 571-584. [CrossRef]

44. Castells, M. The Internet Galaxy: Reflections on the Internet, Business, and Society. Q. Rev. Distance Educ. 2003, 5, 66-68.

45. Parpart, J.L.; Rai, S.M.; Staudt, K.A. Rethinking Empowerment: Gender and Development in a Global/Local World; Routledge: New York, NY, USA, 2003.

46. Peterson, N.A.; Lowe, J.B.; Aquilino, M.L.; Schneider, J.E. Linking social cohesion and gender to intrapersonal and interactional empowerment: Support and new implications for theory. J. Commun. Psychol. 2005, 33, 233-244. [CrossRef]

47. Lincoln, N.D.; Travers, C.; Ackers, P.; Wilkinson, A. The meaning of empowerment: The interdisciplinary etymology of a new management concept. Int. J. Manag. Rev. 2002, 4, 271-290. [CrossRef]

48. Wandersman, A.; Florin, P. Citizen Participation and Community Organizations; Springer: New York, NY, USA, 2000; pp. 247-272.

49. Bertot, J.C.; Jaeger, P.T.; Grimes, J.M. Using ICTs to create a culture of transparency: E-government and social media as openness and anti-corruption tools for societies. Gov. Inf. Q. 2010, 27, 264-271. [CrossRef]

50. Thomas, K.W.; Velthouse, B.A. Cognitive elements of empowerment: An "interpretive" model of intrinsic task motivation. Acad. Manag. Rev. 1990, 15, 666-681.

51. Kieffer, C.H. Citizen empowerment: A developmental perspective. Prevent. Hum. Serv. 1984, 3, 9-36. [CrossRef]

52. Van den Eynde, J.; Veno, A. Coping with disastrous events: An empowerment model of community healing. In Response to Disaster: Psychosocial, Community, Ecological Approaches; Francis Group: London, UK; New York, NY, USA, 1999; pp. 167-192. 
53. Qureshi, S. The forgotten awaken: ICTâ ${ }^{\mathrm{TM}} \mathrm{S}$ evolving role in the roots of mass discontent. Inf. Technol. Dev. 2017, 23, 1-17. [CrossRef]

54. Oreglia, E.; Srinivasan, J. ICT, intermediaries, and the transformation of gendered power structures. Math. Notes 2016, 81, 193-200. [CrossRef]

55. Kolko, J. Broadband and local growth. J. Urban Econ. 2012, 71, 100-113. [CrossRef]

56. Kankanhalli, A.; Ye, H. User Service Innovation on Mobile Phone Platforms: Investigating Impacts of Lead Userness, Toolkit Support, and Design Autonomy. MIS Q. 2018, 42, 165-187.

57. Brynjolfsson, E.; Smith, M.D. Frictionless Commerce? A Comparison of Internet and Conventional Retailers. Manag. Sci. 2000, 46, 563-585. [CrossRef]

58. Lin, X.; Wu, R.; Lim, Y.-T.; Han, J.; Chen, S.-C. Understanding the Sustainable Usage Intention of Mobile Payment Technology in Korea: Cross-Countries Comparison of Chinese and Korean Users. Sustainability 2019, 11, 5532. [CrossRef]

59. Aker, J.C.; Ghosh, I.; Burrell, J. The promise (and pitfalls) of ICT for agriculture initiatives. Agric. Econ. 2016, 47, 35-48. [CrossRef]

60. Pan, S.L.; Tan, B. Demystifying case research: A structured-pragmatic-situational (SPS) approach to conducting case studies. Inf. Organ. 2011, 21, 161-176. [CrossRef]

61. Siggelkow, N. Persuasion with case studies. Acad. Manag. J. 2007, 50, 20-24. [CrossRef]

62. Eisenhardt, K.M. Building Theories from Case Study Research. Acad. Manag. Rev. 1989, 14, 532-550. [CrossRef]

63. Walsham, G. Interpretive case studies in IS research: Nature and method. Eur. J. Inf. Syst. 1995, 4, 74-81. [CrossRef]

64. Klein, H.K.; Myers, M.D. A set of principles for conducting and evaluating interpretive field studies in information systems. MIS Q. 1999, 23, 67-93. [CrossRef]

65. Dubé, L.; Paré, G. Rigor In Information Systems Positivist Case Research: Current Practices, Trends, and Recommendations. MIS Q. 2003, 27, 597-636. [CrossRef]

66. Tim, Y.; Pan, S.L.; Bahri, S.; Fauzi, A. Digitally enabled affordances for community-driven environmental movement in rural Malaysia. Inf. Syst. J. 2018, 28, 48-75. [CrossRef]

(C) 2020 by the authors. Licensee MDPI, Basel, Switzerland. This article is an open access article distributed under the terms and conditions of the Creative Commons Attribution (CC BY) license (http://creativecommons.org/licenses/by/4.0/). 